\title{
Mercury bioaccumulation in fishes of a paddy field in Southern of Brazil
}

Bioacumulação de mercúrio em peixes em uma lavoura de arroz no Sul do Brasil

Vinicius Tavares Kütter ${ }^{1}$, Mateus Tavares Kütter ${ }^{2}$, Emmanoel Vieira Silva-Filho ${ }^{1}$,

Eduardo Duarte Marques ${ }^{3}$, Olga Venimar de Oliveira Gomes ${ }^{1}$ and Nicolai Mirlean ${ }^{4}$

${ }^{1}$ Departamento de Geoquímica, Universidade Federal Fluminense - UFF, Outeiro São João Batista, s/n, CEP 24020141, Niterói, RJ, Brazil

e-mail: viniciuskutter@yahoo.com.br; geoemma@vm.uff.br; olgagomes@id.uff.br

${ }^{2}$ Instituto de Biologia, Universidade Federal do Rio Grande - FURG, Av. Itália, Km 8, CEP 96201900, Rio Grande, RS, Brazil

e-mail: kutter.m.t@gmail.com

${ }^{3}$ Escritório Regional Belo Horizonte, Serviço Geológico do Brasil - CPRM,

CEP 30140-002, Belo Horizonte, MG, Brazil

e-mail: Eduardo.marques@cprm.gov.br

${ }_{4}^{4}$ Instituto de Oceanografia, Universidade Federal do Rio Grande - FURG, Av. Itália, Km 8, CEP 96201900, Rio Grande, RS, Brazil

e-mail: dgeonmir@furg.br

\begin{abstract}
Aim: The aim of present study was to evaluate the $\mathrm{Hg}$ concentration in two species of fish (Astyanax sp and Corydoras paleatus) and its potential use as a biomonitor, in order to know if the use of pesticides and fertilizers in paddy can enhance the $\mathrm{Hg}$ contamination to adjacent aquatic environment. Methods: Soil, suspended particulate matter and fish samples were sampled in a paddy field in South Brazil A cold vapor system, coupled with a GBC 932 atomic absorption spectrophotometer was used for total $\mathrm{Hg}$ determinations in samples. Results: The paddy soil shows $\mathrm{Hg}$ concentration 2-fold higher (mean $31 \mathrm{ng} \mathrm{g}^{-1}$ ) in comparison to background areas (not cultivated). Suspended particle matter $\mathrm{Hg}$ concentration in paddy channels (mean $232.5 \pm 44.2 \mathrm{ng} \mathrm{g}^{-1}$ ) are 1.5 times higher than the regional background. The analyzed fish specimens Astyanax sp in paddy showed $\mathrm{Hg}$ concentration 4-fold higher and significant different to background area. The mean $\mathrm{Hg}$ concentration in fish was: $51.7 \pm 19.5 \mathrm{ng} \mathrm{g}^{-1}$ in Astyanax sp and 156.8 $\pm 44.0 \mathrm{ng} \mathrm{g}^{-1}$ in Corydoras paleatus. Conclusions: Considering the linear regression and Man whitney test hypothesis to $\mathrm{Hg}$ concentration in fish tissue from paddy suggests that Astyanax sp. can be a good biomonitor of $\mathrm{Hg}$ contamination, whereas Corydoras paleatus is a potential biomonitor. However, more studies with Corydoras are necessary in order to aggregate consistency to this hypothesis.
\end{abstract}

Keywords: biomonitoring; fish; mercury; contamination; Pampa biome.

Resumo: Objetivo: O objetivo do presente estudo foi avaliar a concentração de $\mathrm{Hg}$ em duas espécies de peixes (Astyanax sp e Corydoras paleatus) e seu uso potencial como biomonitor, a fim de saber se o uso de pesticidas e fertilizantes na lavoura pode levar a contaminação por $\mathrm{Hg}$ ao ambiente aquático adjacente. Métodos: Solo, material particulado em suspensão e amostras de peixes foram coletadas em um campo de arroz no sul do Brasil. Um sistema de vapor frio acoplado a um espectrofotômetro de absorção atômica (GBC 932) foi usado para as determinaçóes de Hg total nas amostras. Resultados: $\mathrm{O}$ solo da lavoura de arroz apresentou concentração de $\mathrm{Hg} 2$ vezes mais elevada (média de $31 \mathrm{ng} \mathrm{g}^{-1}$ ), em comparaçáo com a área controle (não cultivado). A concentração de $\mathrm{Hg}$ no material particulado em suspensão dos canais de irrigaçáo do arroz (média de 232,5 $\pm 44,2 \mathrm{ng} \mathrm{g}^{-1}$ ) é 1,5 vezes mais elevada do que na área controle. Os espécimes de peixes Astyanax sp analisados na área de cultivo mostraram concentração de $\mathrm{Hg} 4$ vezes maior e, significativamente diferentes da área controle. A concentração média de $\mathrm{Hg}$ em peixes foi: 51,7 $\pm 19,5 \mathrm{ng} \mathrm{g}^{-1}$ em Astyanax sp e 156,8 $\pm 44,0 \mathrm{ng} \mathrm{g}^{-1} \mathrm{em}^{-}$ Corydoras paleatus. Conclusóes: Considerando a regressão linear e o teste de hipótese de 
de Man Whitney para a concentraçáo de $\mathrm{Hg}$ em tecidos de peixes da lavoura de arroz, sugere que Astyanax sp. pode ser uma bom biomonitor de contaminaçáo $\mathrm{Hg}$, enquanto Corydoras paleatus é um biomonitor potencial. No entanto, mais estudos com Corydoras são necessárias, a fim de agregar consistência a este estudo.

Palavras-chave: biomonitoramento; peixe; mercúrio; contaminação; bioma Pampa.

\section{Introduction}

Mercury $(\mathrm{Hg})$ is considered a highly toxic metal and has been used in the composition of pesticides utilized in rice fields (Smart \& Hill, 1968). In Brazil, the use of pesticides containing $\mathrm{Hg}$ was banned in the 70's. Although the input of anthropogenic $\mathrm{Hg}$ had been stopped at these sites after the banishment, its effects persist in the environment and biota. Studies on paddies in Japan have reported an insignificant reduction of $\mathrm{Hg}$ soil contamination over eight years of study (Nakagawa \& Yumita, 1998). Furthermore, more recent studies in paddies reported high concentration of methylmercury $(\mathrm{MeHg})$ in rice grains (Zhang et al., 2010a,b; Zhao et al., 2010; Zhu et al., 2011; Peng et al., 2012; Rothenberg et al., 2012; Li et al., 2013).

In Brazil, the study developed by Silva et al. (2010) found $\mathrm{Hg}$ concentrations ranging from 2.2 to $4.4 \mathrm{ng} \mathrm{g}^{-1}$ in rice grains. Actually the large use of fertilizers in the rice production can intensify the methylation process in paddy fields due to bacteria growth stimulation.

Amongst the three $\mathrm{Hg}$ forms, the organic form $\mathrm{MeHg}$ is the most toxic to humans even in low concentrations (Zahir et al., 2005). Although $\mathrm{Hg}$ presents low concentration in water, it can be potentially biomagnified, reaching very higher concentrations in predatory fish, which can result in an increased risk of developing health problems when consumed by humans (NRC, 2000).

According to the report of the Committee on the Toxicological Effects of Methylmercury in the United States, the major source of human exposure to $\mathrm{MeHg}$ is the consumption of contaminated fish (NRC, 2000). Innumerous studies have been demonstrated that more than $80 \%$ of the total $\mathrm{Hg}$ present in fish tissue is in the form of $\mathrm{MeHg}$ (Silva et al., 2011; Kannan et al., 1998).

The characteristics of paddy are favorable to the process of $\mathrm{Hg}$ conversion into $\mathrm{MeHg}$ by anaerobic microorganisms (Rothenberg \& Feng, 2012). Moreover, some studies have demonstrated that this process can also occur in the intestine of some fish species when they are fed with inorganic mercury (Rudd et al., 1980; Leaner \& Mason, 2002).
Since 1908, the rice production is cultivated in paddies in the Southern Brazil (Beskow, 1986). Nowadays, Brazil is the ninth largest rice producer in the world (Wong, 2004). The Rio Grande do Sul State produces $68 \%$ of the national production (CONAB, 2013). This region is part of the Pampa Biome that covers about $63 \%$ of Rio Grande do Sul State (IBAMA, 2004).

The Pampa has a great biodiversity including endemic species, some of them endangered or at risk of extinction (Marques et al., 2002). Notwithstanding the considerable number of endangered species, this region has received little attention in terms of environmental research (Bencke, 2010).

The paddy has a considerable impact on aquatic animals, since many species that inhabit nearest areas, swamps and lagoons, move to them after the flood. Furthermore, this environment has great ecological significance because it represents an important feeding, resting and breeding area for birds, including migratory species that comes from North and South America's (Dias \& Burger, 2005).

Studies with fish demonstrated that this animal group is a good indicator of environmental health (Van der Oost et al, 2003; Raimundo et al., 2011). In this group, the main $\mathrm{Hg}$ incorporation in tissue occurs through feeding (Kidd et al., 1995; Snodgrass et al., 2000). The MeHg is absorbed by the gut and accumulated in tissues, where it can be biomagnified because of the long half-life of this compound (Lacerda \& Malm, 2008). Therefore, as predator fish are in the top of the food web, they have the highest concentrations of this metal in relation to species which are at the bottom.

Mirlean et al. (2005), who investigated $\mathrm{Hg}$ levels in lakes near the paddy region in the Southern Brazil, found that the main source of $\mathrm{Hg}$ in this area is the atmospheric deposition. In this same study, the authors have proposed the use of Astyanax sp as a bioindicator of $\mathrm{Hg}$ contamination in studied area, once these species have shown a good correlation with $\mathrm{Hg}$ levels in the environment.

The genus Astyanax has been appointed by several authors as an excellent biomonitor of aquatic ecosystems, responses of countless biomarkers, such as histopathological assays (Prado et al., 2011; 
Flores-Lopes \& Thomaz, 2011; Schulz \& MartinsJunior, 2001), micronucleus genotoxicity tests (Bogoni et al., 2014; Pantaleão et al., 2006) comet assay (Ramsdorf et al., 2012), and also hepatic porphyrin (Carrasco-Letelier et al., 2006).

The Astyanax sp and Corydoras paleatus are widely found in paddies in Southern Brazil, and are a food source to a large number of birds and mammals that use the paddy as a feeding area. These fish species are in the base of the aquatic food web. Therefore, they occupy a key position in the $\mathrm{Hg}$ bioaccumulation and transfer in the food web of this environment.

The aim of present study was to evaluate the $\mathrm{Hg}$ concentration in two species of fish (Astyanax $\mathrm{sp}$ and Corydoras paleatus) and its potential use as a biomonitor, in order to know if the use of pesticides and fertilizers in paddy can enhance the $\mathrm{Hg}$ contamination to adjacent aquatic environment.

We hypothesize the use of pesticides and fertilizers in rice paddy fields are a potential $\mathrm{Hg}$ source to adjacent aquatic environment.

\section{Material and Methods}

\subsection{Study sites and species}

The studied site is located at the municipality of Rio Grande-RS, in the region of the swamppampas, Coastal Southern Brazil (Figure 1).
This region is characterized by a coastal plain where major soil types are Planosol, Gleysol, Podzol and quartz sands, comprised of medium/fine sand and clay (Tagliani, 1997). Around the paddy fields, there are artificial channels used for drainage and irrigation, connecting this environment to natural lakes and wetlands with great biodiversity (fish, crustaceans, amphibians, aquatic birds, etc.) and allows the migration of the aquatic fauna between these sites.

During the growth period, the rice farms remain flooded for 80-100 days and many wild aquatic organisms inhabit this environment. Also in this period fertilizers, pesticides and herbicides are applied into the crops. In the harvest period the crops are drained and the animals are found in the channel, lakes and wetlands.

The sampling campaign was carried out in the summer of 2005, in a farm located at the boarder of the highway RS-473 in the period immediately after the rice harvest. The water used for rice irrigation comes by diversion from São Gonçalo River. One $40 \mathrm{~cm}$ core of paddy soil was collected. In the paddy drainage channel, four samples of suspended particulate matter (SPM) and the two wild fish species (Astyanax sp and Corydoras paleatus) were collected.

Regarding the biology of the fish species, the Astyanax genus feeding in the water column,

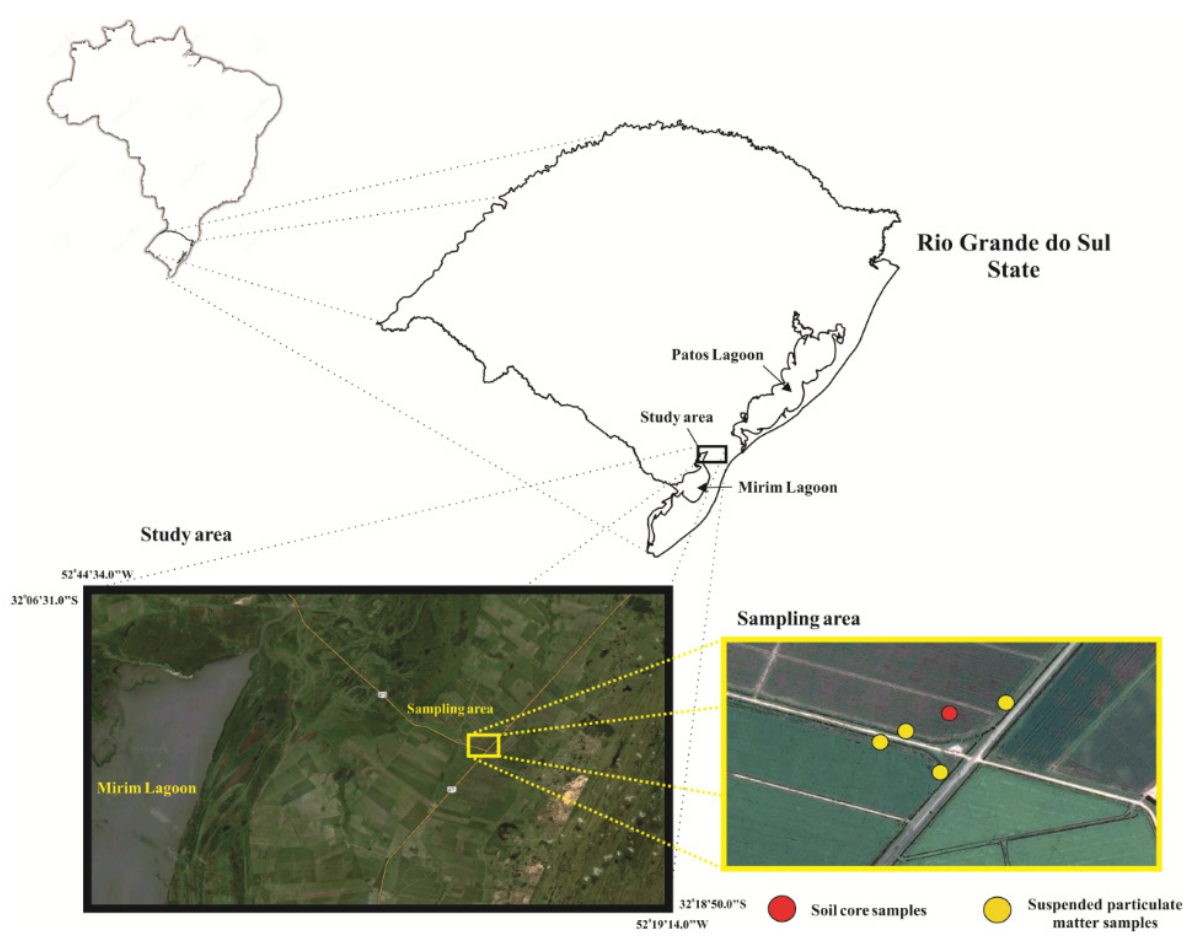

Figure 1. Location of the sampling area. 
consuming mainly zooplankton, fish eggs, and insects, whereas the Corydoras paleatus are bottom feeders, eating insects, small invertebrates and organic detritus (Moresco \& Bemvenuti 2005). In the swamp-pampas of Southern Brazil the most abundant species are: Astyanax jacuhiensis, Astyanax eigenmanniorum and Astyanax fasciatus (Moresco \& Bemvenuti 2005).

The paddy soil core was obtained employing acrylic tube sampler. In the laboratory, the soil core was fractionated in: $0-15 \mathrm{~cm}, 15-30 \mathrm{~cm}$ and $30-40 \mathrm{~cm}$. Each part of the soil core was homogenized and an aliquot of this homogenates were utilized in the total and $<63 \mu \mathrm{m}$ fractions for mercury determination.

The paddy drainage water was sampled in $1.5 \mathrm{~L}$ plastic bottles previous cleaned with $\mathrm{HCl} 10 \%(\mathrm{v} / \mathrm{v})$. The water was maintained at temperature of $4{ }^{\circ} \mathrm{C}$ in cooler boxes until arrival to laboratory. At the laboratory, the water was filtered in acetate cellulose membranes $(0.45 \mu \mathrm{m})$ in a vacuum system for suspended particulate matter (SPM) quantification.

The fish species were collecting by netting. A total of 25 specimens of Astyanax sp and 10 of Corydora paleatus were obtained. In the laboratory, the fork lengths were determined, and then muscle tissue samples were removed for $\mathrm{Hg}$ analysis.

The results obtained in the present study were compared to literature data from background area (Federally-protected Taim Ecological Station). This area is located $80 \mathrm{Km}$ away from farming investigated in the present work.

\subsection{Sample digestion and total mercury analysis}

Digestion methods for soil, SPM and fish tissues were the same proposed by Zhou \& Wong (2000). Briefly, aliquots $(0.5 \mathrm{~g})$ of the soil and SPM samples were digested in $15 \mathrm{ml}$ of concentrated $\mathrm{H}_{2} \mathrm{SO}_{4}$ and $\mathrm{HNO}_{3}(2: 1 \mathrm{v} / \mathrm{v})$ in a $60{ }^{\circ} \mathrm{C}$ water bath. Digestion was proceeded until the solution was clear, then the digestion flasks were transferred to an ice bath, and $6 \% \mathrm{KMnO}_{4}$ solution was added slowly, until the digest turned purple. Five milliliters of $5 \% \mathrm{~K}_{2} \mathrm{~S}_{2} \mathrm{O}_{8}$ was then added to each flask to ensure complete oxidation of organic mercury compounds.

Fish tissue samples were pre-digested in $8 \mathrm{ml}$ of concentrated $\mathrm{HNO}_{3}$ and $\mathrm{H}_{2} \mathrm{SO}_{4}(2: 1 \mathrm{v} / \mathrm{v})$ at $25^{\circ} \mathrm{C}$ for $3 \mathrm{~h}$, then at $60^{\circ} \mathrm{C}$ for $5 \mathrm{~h}$. Five milliliters of $30 \% \mathrm{H}_{2} \mathrm{O}_{2}$ were added to the samples in $0.5 \mathrm{ml}$ increments, with time enough for decreasing of foaming between additions. The temperature was then raised to $65^{\circ} \mathrm{C}$, and digestion proceeded until the samples turned colorless or light yellow. A cold vapor system, coupled with a GBC 932 atomic absorption spectrophotometer, was used for total $\mathrm{Hg}$ determinations in digested soil, SPM and fish samples.

During the analysis, the $\mathrm{Hg}$ liberated by the reduction was purged with argon, and collected on a gold wool trap connected to a GBC HG3000 hydride generation system. An additional gold trap in the gas line stripped mercury from the carrier gas. Concentrations were then determined with the GBC atomic absorption spectrophotometer. The spectrophotometer has a detection limit of $0.4 \mathrm{ng} \mathrm{L}^{-1}$.

All samples were analyzed in triplicate. Coefficients of variation for all triplicates were $<6 \%$. The accuracy and precision of $\mathrm{Hg}$ analysis were verified by sequential digestion and analysis of certified reference materials (PACS-2 for sediment, and IAEA 350 tuna homogenates for fish muscle). Mean $\mathrm{Hg}$ recovery was within the $97 \%$ confidence interval for both materials, indicating high accuracy, and the coefficient of variation for six analysis was $<5 \%$, indicating high precision.

Mercury concentrations in fish are expected to increase with age due to cumulative exposure; however, to determine fish ages is not often possible. Fish lengths and weights are typically used as surrogates for age, and positive relationships between $\mathrm{Hg}$ concentrations and both size and age have been reported for lake fishes (Grieb et al., 1990). A linear regression was computed to assess the relationship between tissue $\mathrm{Hg}$ and fork length. Furthermore, a Man Whitney test was employed in Statistica 8.0 to test the differences of $\mathrm{Hg}$ concentration in fish from different areas are significant.

\section{Results and Discussion}

\subsection{Mercury in the Soil and Suspended particulate matter}

The mercury concentration in the soil (fraction $<63 \mu \mathrm{m}$ ) was around 2 times higher than found in the total fraction (Table 1).

This result agrees with that found by Conceição (2005) for the regional background. It was not found any considerable variability in the $\mathrm{Hg}$ concentration in the different soil depths evaluated. This is probably because the soil is plowed every year for rice planting, leading to a homogenization among the soil layers.

According to Mirlean \& Oliveira (2006), the unpolluted soils (fraction $<63 \mu \mathrm{m}$ ) in this region presents average $\mathrm{Hg}$ concentration of $27 \mathrm{ng} \mathrm{g}^{-1}$ (ranging from 10 to $50 \mathrm{ng} \mathrm{g}^{-1}$ ). The results found 
in the paddy soil indicate that it contains a small enrichment in $\mathrm{Hg}$ in comparison to the regional background. The same result is found in the total soil fraction, since Conceição (2005) found a mean $\mathrm{Hg}$ concentration of $15 \mathrm{ng} \mathrm{g}^{-1}$ in this fraction.

The probable source of mercury enrichment in the paddy soil is the use of fertilizers and/or pesticides. Some studies with fertilizers described mercury concentrations of $147,000.0 \pm 38,235,000.0 \pm 98$ and $196,000.0 \pm 65 \mathrm{ng} \mathrm{g}^{-1}$ in superphosphate, triple superphosphate, and NPK fertilizer, respectively (Mirlean et al., 2008). The low Hg enrichment of the soil could be related to the leaching process.

After the soil fertilization and rice planting, the area is flooded and due to the predominance of fine grained soil, the SPM in water column allows the $\mathrm{Hg}$ transport to adjacent aquatic environments. These processes were found by Aomine et al. (1967), which showed the mercury sprayed onto crops would be partly retained by the soil in paddy conditions for a considerable period whereas another fraction would be removed with percolation and run-off water and also be absorbed by plant roots. Moreover, Aomine et al. (1967) showed that largest part of $\mathrm{Hg}$ applied in the paddy is transported by and deposited in the rivers bottom sediment from the adjacent watershed.

The mean $\mathrm{Hg}$ concentration in suspended particulate matter in the paddy was $232.5 \pm 44.2$ $\mathrm{ng} \mathrm{g}^{-1}$. This value is about 5 times higher than that found in the fine soil fraction $(<63 \mu \mathrm{m})$ and lower than that found in SPM at hydric compartments contaminated by gold mining and urban effluent (Table 2). However, it is similar to that found by Kütter (2006) from an industrial area in the same region (Table 2). The $\mathrm{Hg}$ concentrations in SPM paddy was about 1.5 times higher than the regional background and up to 4 times higher compared to remote areas in Amazon (Brabo et al., 2003).

Silva et al. (2009) demonstrated that watershed land use influences Hg levels in fishes of Amazon biome. According to this work, watershed with highest aquatic vegetation density and lowest forest cover showed ichthyofauna with highest $\mathrm{Hg}$ concentration. Conversely, the watershed with the highest forest cover and low aquatic vegetation density showed the lowest mercury concentration in fish community.

Lacerda et al. (2012), demonstrated that the change of land use in Amazon region is the main cause of $\mathrm{Hg}$ increase in top food web predatory fish. Furthermore, the SPM represents $90 \%$ of the total $\mathrm{Hg}$ present in the water river. According to Lacerda et al. (2012) the SPM has a key role in the process of fish $\mathrm{Hg}$ increase.

In Amazon biome, soils under any type of local cultivation (fallow, pasture, orchards, banana plantations) were characterized by cation enrichment

Table 1. Mercury concentration $\left(\mathrm{ng} \mathrm{g}^{-1}\right)$ in soils from the study area.

\begin{tabular}{cccc}
\hline \multirow{2}{*}{ Site } & \multirow{2}{*}{ Deep $(\mathbf{c m})$} & \multicolumn{2}{c}{ Hg concentration $\left(\mathbf{n g ~ ~ ^ { - 1 } )}\right.$} \\
\cline { 3 - 4 } & & $\begin{array}{c}\text { Soil (fraction }<63 \boldsymbol{\mu m}) \\
(\mathbf{n}=3)\end{array}$ & $\begin{array}{c}\text { Soil (Total) } \\
(\mathbf{n}=\mathbf{3})\end{array}$ \\
\hline \multirow{3}{*}{ Paddy field } & $0-15$ & $57.0 \pm 4.0$ & $28.5 \pm 4.1$ \\
& $15-30$ & $63.5 \pm 2.7$ & $29.5 \pm 3.6$ \\
& $30-40$ & $54.3 \pm 3.3$ & $34.8 \pm 1.2$ \\
\hline
\end{tabular}

Table 2. Comparison among different sources of $\mathrm{Hg}$ in SPM for different sites in Brazil.

\begin{tabular}{lcc}
\multicolumn{1}{c}{ Site } & $\begin{array}{c}\text { Hg ng g } \\
\text { average (range) }\end{array}$ & Reference \\
\hline Domestic effluent - Rio Grande City & $5530(460-21140)$ & Mirlean et al. (2003) \\
Mixes effluent - Rio Grande City & $1180(120-3970)$ & Mirlean et al. (2003) \\
Industrial effluent - Rio Grande City & $650(140-1940)$ & Mirlean et al. (2003) \\
Rain water runoff - Rio Grande City & $350(70-1100)$ & Mirlean et al. (2003) \\
Paddy channel - Rio Grande City & $232.5(170.3-275)$ & This work \\
Industrial Area - Pelotas RS & 258.8 & Kütter (2006) \\
Natural Reserve (background regional) - Rio Grande City & 163.4 & Kütter (2006) \\
Gold mining area - Viseu City - Pará & $201.5(<8-900)$ & Vieira \& Passarelli (1996) \\
Acre State rivers - Amazon Forest & $60(1-220)$ & Brabo et al. (2003) \\
Gold mining tailing deposit - Poconé city & $(<20-610)$ & Lacerda et al. (1991) \\
Paraíba do Sul River - Rio de Janeiro & $522.8(233-964)$ & Molisani et al. (2007) \\
Acre River - Amazon Forest & $98(67-220)$ & Mascarenhas et al. (2004) \\
\hline
\end{tabular}


associated with slash-and-burn activities, leading to loss of $\mathrm{Hg}$, compared to levels measured in soils under forest cover (Farella et al., 2006, 2007). Pampa biome soils under rice cultivation are characterized by adduction of fertilizers and calcareous ( $\mathrm{pH}$ soil corrector) by the periodic flooding, leading to $\mathrm{Hg}$ availability for biota incorporation.

\subsection{Mercury in fishes}

The linear regression of $\mathrm{Hg}$ concentrations in the fish tissue versus fish size show an increasing trend to bioaccumulation in both species investigated (Figure 2).

In Astyanax sp the $\mathrm{Hg}$ average concentration was $51.7 \pm 19.5 \mathrm{ng} \mathrm{g}^{-1}$ (26.1 to $51.7 \mathrm{ng} \mathrm{g}^{-1}$ ), whereas Corydoras paleatus has averaged of 156.8 $\pm 44.0 \mathrm{ng} \mathrm{g}^{-1}$ (ranging from 85.4 to $222.3 \mathrm{ng} \mathrm{g}^{-1}$ ). This difference in $\mathrm{Hg}$ concentration between Astyanax sp and Corydoras paleatus may be related to feed habits as well as to distinct physiological characteristics of the two species. The Corydoras paleatus is detritivorous feeding organic matter and invertebrates from bottom, on the other hand, the Astyanax $s p$ is omnivorous feeding plankton and invertebrates from water (Moresco \& Bemvenuti, 2005).

The maximum size attained by Astyanax $s p$ as an adult is greater than the Corydoras paleatus. The highest concentration of $\mathrm{Hg}$ found in Corydoras paleatus may be related to the fact that this fish species grows less in comparison to Astyanax sp.

The $\mathrm{Hg}$ concentration in Astyanax $s p$ is approximately 4 -fold higher in the paddy area when compared to individuals of the same size of the background area (Mirlean et al., 2005) (Figure 3). Moreover, these differences between the paddy field and background area are significantly different $\mathrm{p}<0.05$ (Man-Whitney test). However, the $\mathrm{Hg}$ concentration in Astyanax sp from paddy is 2.6 and 1.3 times lower than observed in individuals from industrial and suburban areas, respectively (Table 3).

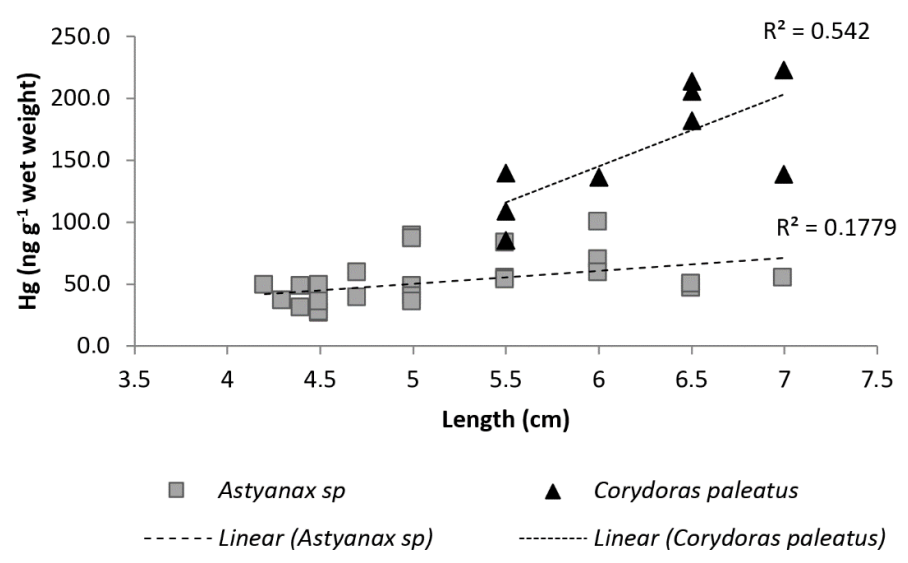

Figure 2. Relation between Hg concentration in Astyanax sp $(\mathrm{n}=25)$ and Corydoras paleatus $(\mathrm{n}=10)$ tissues and sizes sampled from a paddy.

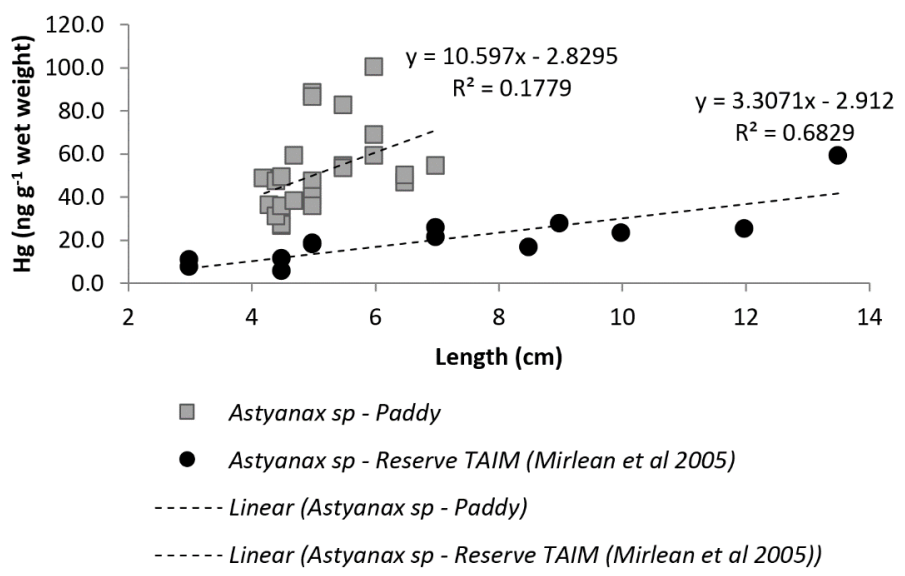

Figure 3. Mercury concentration in Astyanax sp from paddy in comparison to data from Mirlean et al. (2005) nature reserve. 


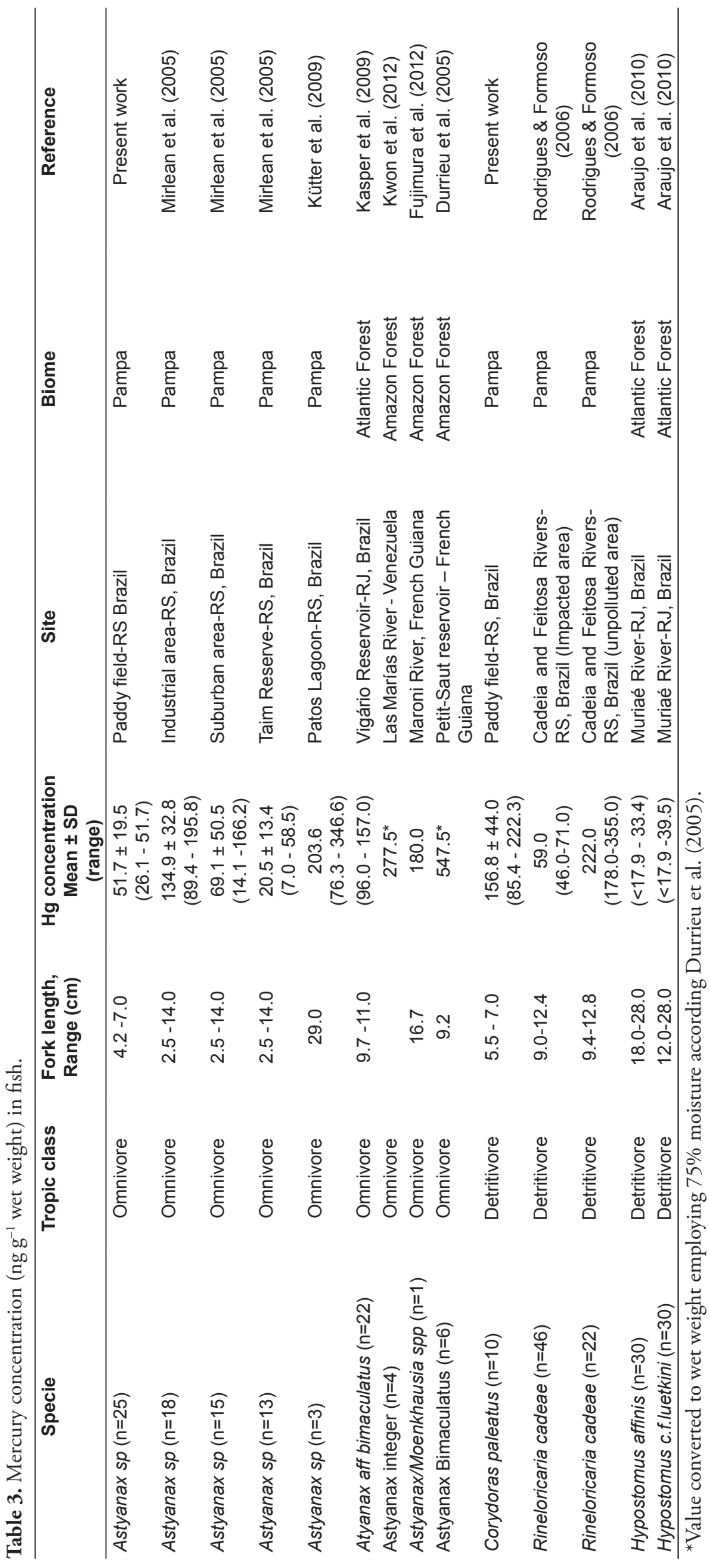


The highest $\mathrm{Hg}$ concentrations in Astyanax $s p$ are reported in hydroelectric reservoir from Amazon region (Durrieu et al., 2005). These values are related to methylation process that is increased in those environments (Hylander et al., 2006; Montgomery et al., 2000). Even in the background areas from the Amazon region the $\mathrm{Hg}$ values in Astyanax sp are at least 5 times higher than that found in paddy fields in Southern Brazil (Kwon et al., 2012; Fujimura et al., 2012) (Table 3).

In another study developed in a reservoir in Southeastern Brazil, Kasper et al. (2009) found Hg concentration 1.8 to 3.0 times higher in Astyanax sp in comparison to paddy field from Pampa (Table 3 ). These reservoirs receive water from a polluted river, Paraíba do Sul, that cross the biggest Brazilian industrial park.

Due to the fact that the present work is the first study to show data on $\mathrm{Hg}$ accumulation in Corydoras paleatus, we opted to compare the data from paddy field with others detritivores species. The Corydoras paleatus from paddy showed $\mathrm{Hg}$ concentration 3 times higher than that found in Rineloricaria cadeae in an unpolluted area from Pampa biome (Rodrigues \& Formoso, 2006). On the other hand, tissue $\mathrm{Hg}$ concentrations in Rineloricaria cadeae from tanneries impacted area are 1.4 times higher than Corydoras paleatus (Table 3) in our study. Other detritivorous fish, Hypostomus sp showed tissue $\mathrm{Hg}$ concentration 4 times lower in unpolluted area than Corydoras paleatus from paddy (Table 3).

\section{Conclusion}

The results demonstrated that the levels of $\mathrm{Hg}$ in fish found in the paddy are higher than in near sites without human activities ( control area,Taim reserve). This result, suggest that the use of pesticides and fertilizers in paddy fields can enhance the mercury contamination to adjacent aquatic ecosystems. Furthermore, considering the linear regression and Man whitney test hypothesis to $\mathrm{Hg}$ concentration in fish tissue from paddy suggests that Astyanax sp. can be a good biomonitor of $\mathrm{Hg}$ contamination, whereas Corydoras paleatus is a potential biomonitor. However, more studies with Corydoras are necessary in order to aggregate consistency to this hypothesis.

\section{References}

AOMINE, S., KAWASAKI, H. and INOUE, K. Retention of mercury by soils. Soil Science and Plant Nutrition, 1967, 13(6), 187-188. http://dx.doi.org/ 10.1080/00380768.1967.10431994.
ARAUJO, B.F., CARVALHO, C.E.V., ANDRADE, D.R. and GOMES, R.S. Distribuição de mercúrio em tecido muscular de Hypostomus affinis (Steindachner, 1877) e Hypostomus c.f.luetkini (Barlenger, 1887) do Rio Muriaé, Itaperuna-RJ. Journal of the Brazilian Society of Ecotoxicology, 2010, 5(1), 49-54. http:// dx.doi.org/10.5132/jbse.2010.01.008.

BENCKE, G. New and significant bird records from Rio Grande do Sul, with comments on biogeography and conservation of the southern Brazilian avifauna. Iheringia Série Zoologia, 2010, 100(4), 391-402. http://dx.doi.org/10.1590/S007347212010000400014.

BESKOW, PR. O arrendamento capitalista na agricultura: evolução e situação atual da economia do arroz no Rio Grande do Sul. Cadernos de Difusão de Tecnologia, 1986, 3(2), 343-350 [viewed 16 Aug. 2014]. Available from: https://seer.sct.embrapa.br/index. php/cct/article/viewFile/9216/5253.

BOGONI, J.A., ARMILIATO, N., ARALDI-FAVASSA, C.T. and TECHIO, V.H. Genotoxicity in Astyanax bimaculatus (Twospot Astyanax) exposed to the waters of Engano River (Brazil) as determined by micronucleus tests in erythrocytes. Archives of Environmental Contamination and Toxicology, 2014, 66(3), 441-449. http://dx.doi.org/10.1007/s00244013-9990-5. PMid:24435477

BRABO, E.S., ANGÉLICA, R.S., SILVA, A.P., FAIAL, K.R.F., MASCARENHAS, A.F.S., SANTOS, E.C.O., JESUS, I.M. and LOUREIRO, E.C.B. Assessment of Mercury levels in soils, Waters, bottom sediments and fishes of Acre state in Brazilian Amazon. Water, Air, and Soil Pollution, 2003, 147(1-4), 61-77. http://dx.doi.org/10.1023/A:1024510312250.

CARRASCO-LETELIER, L., EGUREN, G., DE MELLO, F.T. and GROVES, P.A. Preliminary field study of hepatic porphyrin profiles of Astyanax fasciatus (Teleostei, Characiformes) to define anthropogenic pollution. Chemosphere, 2006, 62(8), 1245-1252. http://dx.doi.org/10.1016/j. chemosphere.2005.07.005. PMid:16153685

COMPANHIA NACIONAL DE ABASTECIMENTO - CONAB. Acompanhamento da safra brasileira de grãos 2012/13-Décimo levantamento - julho. Brasília, 2013 [viewed 16 Aug. 2014]. Available from: http://www.conab.gov.br/OlalaCMS/uploads/ arquivos/13_07_09_09_04_53_boletim_graos_ junho_2013.pdf.

CONCEIÇÃO, C.O. Contaminação dos aterros urbanos por metais pesados no município de Rio Grande - RS [Master thesis]. Rio Grande: Fundação Universidade Federal do Rio Grande, 2005, 108 p. [viewed 16 Aug. 2014]. Available from: http://repositorio.furg. br:8080/handle/1/3527.

DIAS, R.A. and BURGER, M.I. A assembléia de aves de áreas úmidas em dois sistemas de cultivo de arroz 
irrigado no extremo sul do Brasil. Ararajuba, 2005, 1(13), 63-80.

DURRIEU, G., MAURY-BRACHET, R. and BOUDOU, A. Goldmining and mercury contamination of the piscivorous fish Hoplias aimara in French Guiana (Amazon basin). Ecotoxicology and Environmental Safety, 2005, 60(3), 315-323. http://dx.doi.org/10.1016/j.ecoenv.2004.05.004. PMid: 15590010

FARELLA, N., DAVIDSON, R., LUCOTTE, M. and DAIGLE, $S$. Nutrient and mercury variations in soils from family farms of the Tapajós region (Brazilian Amazon): recommendations for better farming. Agriculture, Ecosystems \& Environment, 2007, 120(2-4), 449-462. http://dx.doi.org/10.1016/j. agee.2006.11.003.

FARELLA, N., LUCOTTE, M., DAVIDSON, R. and DAIGLE, S. Mercury release from deforested soils triggered by base cation enrichment. The Science of the Total Environment, 2006, 368(1), 19-29. http://dx.doi.org/10.1016/j.scitotenv.2006.04.025. PMid:16781764

FLORES-LOPES, F. and THOMAZ, A.T. Histopathologic alterations observed in fish gills as a tool in environmental monitoring. Brazilian Journal of Biology, 2011, 71(1), 179-188. http:// dx.doi.org/10.1590/S1519-69842011000100026. PMid:21437416

FUJIMURA, M., MATSUYAMA, A., HARVARD, J.P., BOURDINEAUD, J.-P. and NAKAMURA, K. Mercury contamination in humans in Upper Maroni, French Guiana between 2004 and 2009. Bulletin of Environmental Contamination and Toxicology, 2012, 88(2), 135-139. http://dx.doi.org/10.1007/s00128011-0497-3. PMid:22147084

GRIEB, T.M., DRISCOLL, C.T., SCHOFIELD, C.L., BOWIE, G.L. and PORCELLA, D.B. Factors affecting mercury accumulation in fish in the upper Michigan peninsula. Environmental Toxicology and Chemistry, 1990, 9(7), 919-930. http://dx.doi. org/10.1002/etc.5620090710.

HYLANDER, L.D., GRÖHN, J., TROPP, M., VIKSTRÖM, A., WOLPHER, H., DE CASTRO E SILVA, E., MEILI, M. and OLIVEIRA, L.J. Fish mercury increase in Lago Manso, a new hydroelectric reservoir in tropical Brazil. Journal of Environmental Management, 2006, 81(2), 155-166. http://dx.doi.org/10.1016/j.jenvman.2005.09.025. PMid:16797830

INSTITUTO BRASILEIRO DO MEIO AMBIENTE E DOS RECURSOS NATURAIS RENOVÁVEIS - IBAMA. Estatísticas sobre Unidades de Conservação nos Biomas Brasileiros. 2004 [viewed 16 Aug. 2014]. Available from: http://www.ibama.gov.br.

KANNAN, K., SMITH JUNIOR, R.G., LEE, R.F., WINDOM, H.L., HEITMULLER, P.T., MACAULEY, J.M. and SUMMERS, J.K.
Distribution of total mercury and methyl mercury in water, sediment, and fish from south Florida estuaries. Archives of Environmental Contamination and Toxicology, 1998, 34(2), 109-118. http://dx.doi. org/10.1007/s002449900294. PMid:9469852

KASPER, D., PALERMO, E.F.A., DIAS, A.C.M.I., FERREIRA, G.L., LEITÃO, R.P., BRANCO, C.W.C. and MALM, O. Mercury distribution in different tissues and trophic levels of fish from a tropical reservoir, Brazil. Neotropical Ichthyology, 2009, 7(4), 751-758. http://dx.doi.org/10.1590/ S1679-62252009000400025.

KIDD, K.A., HESSLEIN, R.H., FUDGE, R.J.P. and HALLARD, K.A. The influence of trophic level as measured by delta- $15 \mathrm{~N}$ on mercury concentrations in freshwater organisms. Water, Air, and Soil Pollution, 1995, 80(1-4), 1011-1015. http://dx.doi. org/10.1007/BF01189756.

KÜTTER, V.T. Aspectos da biogeoquímica do mercúrio em lagos na planície costeira do sul do Rio Grande do Sul [Master Thesis]. Rio Grande: Fundação Universidade Federal do Rio Grande, 2006, 93 p. [viewed 16 Aug. 2014]. Available from: http://www. argo.furg.br/bdtd/tde_arquivos/3/TDE-2007-0927T195352Z-50/Publico/Kutter.pdf.

KÜTTER, V.T., MIRLEAN, N., BAISCH, P.R., KÜTTER, M.T. and SILVA-FILHO, E.V. Mercury in freshwater, estuarine, and marine fishes from Southern Brazil and its ecological implication. Environmental Monitoring and Assessment, 2009, 159(1-4), 35-42. http://dx.doi.org/10.1007/s10661008-0610-1. PMid:19011981

KWON, S.Y., MCINTYRE, P.B., FLECKER, A.S. and CAMPBELL, L.M. Mercury biomagnification in the food web of a neotropical stream. The Science of the Total Environment, 2012, 417-418, 92-97. http://dx.doi.org/10.1016/j.scitotenv.2011.11.060. PMid:22257508

LACERDA, L.D. and MALM, O. Contaminação por mercúrio em ecossistemas aquáticos: uma análise das áreas críticas. Estudos Avançados, 2008, 22(63). http:// dx.doi.org/10.1590/S0103-40142008000200011.

LACERDA, L.D., BASTOS, W.R. and ALMEIDA, M.D. The impacts of land use changes in the mercury flux in the Madeira River, Western Amazon. Anais da Academia Brasileira de Ciencias, 2012, 84(1), 69-78. http://dx.doi.org/10.1590/S000137652012000100007. PMid:22441596

LACERDA, L.D., PFEIFFER, W.C., MARINS, R.V., RODRIGUES, S., SOUZA, C.M.M. and BASTOS, W.R. Mercury dispersal in water, sediments and aquatic biota of a gold mining tailing deposit drainage in Poconé, Brazil. Water, Air, and Soil Pollution, 1991, 55(3-4), 283-294. http://dx.doi.org/10.1007/ BF00211194.

LEANER, J.J. and MASON, R.P. Methylmercury accumulation and fluxes across the intestine of 
channel catfish, Ictalurus punctatus. Comparative Biochemistry and Physiology Part C Toxicology \& Pharmacology, 2002, 132(2), 247-259. http:// dx.doi.org/10.1016/S1532-0456(02)00072-8. PMid:12106901

LI, B., SHI, J.B., WANG, X., MENG, M., HUANG, L., QI, X.L., HE, B. and YE, Z.H. Variations and constancy of mercury and methylmercury accumulation in rice grown at contaminated paddy field sites in three Provinces of China. Environmental Pollution, 2013, 181, 91-97. http://dx.doi. org/10.1016/j.envpol.2013.06.021. PMid:23838485

MARQUES, A.A.B., FONTANA, C.S., VELEZ, E. BENCKE, G.A. and REIS, RE. Lista das espécies da fauna ameaçada de extinção no Rio Grande do Sul: Decreto estadual n. 41.672. Porto Alegre, 2002. [viewed 16 Aug. 2014]. Publicaçóes Avulsas FZB, no. 11. Available from: http://www.fzb.rs.gov.br/ upload/1396361091_preliminares.pdf.

MASCARENHAS, A.F.S., BRABO, E.S., SILVA, A.P., FAYAL, K.F., JESUS, I.M. and SANTOS, E.C.O. Mercury concentration assessment in botton sediments and suspended solids from the Acre river, in the State of Acre, Brazil. Acta Amazonica, 2004, 34(1). http://dx.doi.org/10.1590/S004459672004000100008.

MIRLEAN, N. and OLIVEIRA, C. Mercury in coastal reclamation fills in Southernmost Brazil: Historical and environmental facets. Journal of Coastal Research, 2006, 22(6), 1573-1576. http://dx.doi. org/10.2112/04-0352.1.

MIRLEAN, N., ANDRUS, V.E. and BAISCH, P. Mercury pollution sources in sediments of Patos Lagoon Estuary, Southern Brazil. Marine Pollution Bulletin, 2003, 46(3), 331-334. http:// dx.doi.org/10.1016/S0025-326X(02)00404-6. PMid:12604067

MIRLEAN, N., BAISCH, P., MACHADO, I. and SHUMILIN, E. Mercury contamination of soil as the result of long-term phosphate fertilizer production. Bulletin of Environmental Contamination and Toxicology, 2008, 81(3), 305-308. http://dx.doi. org/10.1007/s00128-008-9480-z. PMid:18587516

MIRLEAN, N., LARNED, S.T., NIKORA, V. and KÜTTER, V.T. Mercury in lakes and lake fishes on a conservation-industry gradient in Brazil. Chemosphere, 2005, 60(2), 226-236. http:// dx.doi.org/10.1016/j.chemosphere.2004.12.047. PMid:15914242

MOLISANI, M.M., KJERFVE, B., BARRETO, R. and LACERDA, L.D. Land-sea mercury transport through a modified watershed, SE Brazil. Water Research, 2007, 41(9), 1929-1938. http://dx.doi. org/10.1016/j.watres.2007.02.007. PMid:17382988

MONTGOMERY, S., LUCOTTE, M. and RHEAULT, I. Temporal and spatial influences of flooding on dissolved mercury in boreal reservoirs. The Science of the Total Environment, 2000, 260(1-3), 147-157. http://dx.doi.org/10.1016/S0048-9697(00)00559-3. PMid:11032123

MORESCO, A. and BEMVENUTI, M.A. Peixes: áreas de banhado e lagoas costeiras do extremo sul do Sul do Brasil. Porto Alegre: ABRH, 2005, 63 p.

NAKAGAWA, R. and YUMITA, Y. Change and behavior of residual mercury in paddy soils and rice of Japan. Chemosphere, 1998, 37(8), 1483-1487. http://dx.doi.org/10.1016/S0045-6535(98)00138-6. PMid:9753762

NATIONAL RESEARCH COUNCIL - NRC. Toxicological effects of methylmercury. Washington: Committee on the Toxicological Effects of Methylmercury, Board on Environmental Studies and Toxicology, Commission on Life Sciences, National Research Council, National Academy Press, 2000.

PANTALEÃO, S.M., ALCÂNTARA, A.V., ALVES, J.P. and SPANÓ, M.A. The piscine micronucleus test to assess the impact of pollution on the Japaratuba river in Brazil. Environmental and Molecular Mutagenesis, 2006, 47(3), 219-224. http://dx.doi.org/10.1002/ em.20188. PMid:16388529

PENG, X., LIU, F., WANG, W.-X. and YE, Z. Reducing total mercury and methylmercury accumulation in rice grains through water management and deliberate selection of rice cultivars. Environmental Pollution, 2012, 162, 202-208. http://dx.doi.org/10.1016/j. envpol.2011.11.024. PMid:22243865

PRADO, P.S., SOUZA, C.C., BAZZOLI, N. and RIZZO, E. Reproductive disruption in lambari Astyanax fasciatus from a Southeastern Brazilian reservoir. Ecotoxicology and Environmental Safety, 2011, 74(7), 1879-1887. http://dx.doi. org/10.1016/j.ecoenv.2011.07.017. PMid:21831433

RAIMUNDO, J., PEREIRA, P., CAETANO, M., CABRITA, M.T., VALE, C. Decrease of $\mathrm{Zn}, \mathrm{Cd}$ and $\mathrm{Pb}$ concentrations in marine fish species over a decade as response to reduction of anthropogenic inputs: the example of Tagus estuary. Marine Pollution Bulletin, 2011, 62(12), 2854-2858.

RAMSDORF, W.A., VICARI, T., DE ALMEIDA, M.I., ARTONI, R.F. and CESTARI, M.M. Handling of Astyanax sp. for biomonitoring in Cangüiri Farm within a fountainhead (Iraí River Environment Preservation Area) through the use of genetic biomarkers. Environmental Monitoring and Assessment, 2012, 184(10), 5841-5849. http://dx.doi. org/10.1007/s10661-012-2752-4. PMid:22821320

RODRIGUES, M.K. and FORMOSO, M.L.L. Heavy metals in recent sediments and bottom-fish under the influence of tanneries in South Brazil. Water, Air, and Soil Pollution, 2006, 176(1-4), 307-327. http:// dx.doi.org/10.1007/s11270-006-9170-6. 
ROTHENBERG, S.E., FENG, X. Mercury cycling in a flooded rice paddy. Biogeosciences, 2012, 117(G3), 1-16. http://dx.doi.org/10.1029/2011JG001800.

ROTHENBERG, S.E., FENG, X., ZHOU, W., TU, M., JIN, B. and YOU, J. Environment and genotype controls on mercury accumulation in rice (Oryza sativa L.) cultivated along a contamination gradient in Guizhou, China. The Science of the Total Environment, 2012a, 426, 272-280. http://dx.doi.org/10.1016/j. scitotenv.2012.03.024. PMid:22513403

RUDD, J.W., FURUTANI, A. and TURNER, M.A. Mercury methylation by fish intestinal contents. Applied and Environmental Microbiology, 1980., 40(4), 777-782. PMid:7425625.

SCHULZ, U.H. and MARTINS-JUNIOR, H. Astyanax fasciatus as bioindicator of water pollution of Rio dos Sinos, RS, Brazil. Brazilian Journal of Biology, 2001, 61(4), 615-622. http://dx.doi.org/10.1590/S151969842001000400010. PMid:12071317

SILVA, C.A., TESSIER, E., KÜTTER, V.T., WASSERMAN, J.C., DONARD, O.F.X. and SILVAFILHO, E.M. Mercury speciation in fish of the Cabo Frio upwelling region, SE-Brazil. Brazilian Journal of Oceanography, 2011, 59(3), 259-266. http://dx.doi. org/10.1590/S1679-87592011000300006.

SILVA, D., LUCOTTE, M., PAQUET, S. and DAVIDSON, R. Influence of ecological factors and of land use on mercury levels in fish in the Tapajós River basin, Amazon. Environmental Research, 2009, 109(4), 432-446. http://dx.doi.org/10.1016/j. envres.2009.02.011. PMid:19356749

SILVA, M.J., PAIM, A.P.S., PIMENTEL, M.F., CERVERA, M.L. and DE LA GUARDIA, M. Determination of mercury in rice by cold vapor atomic fluorescence spectrometry after microwaveassisted digestion. Analytica Chimica Acta, 2010, 667(1-2), 43-48. http://dx.doi.org/10.1016/j. aca.2010.04.016. PMid:20441864

SMART, N.A. and HILL, A.R.C. Pesticides residues in foodstuffs in Great Britain. VI. Mercury residues in rice. Journal of the Science of Food and Agriculture, 1968, 19(6), 315-316. http://dx.doi.org/10.1002/ jsfa.2740190606. PMid:5659586

SNODGRASS, J.W., JAGOE, C.H., BRYAN JUNIOR, A.L.B., BRANT, H.A. and BURGER, J. Effects of trophic status and wetland morphology, hydroperiod, and water chemistry on mercury concentrations in fish. Canadian Journal of Fisheries and Aquatic Sciences, 2000, 57(1), 171-180. http://dx.doi. org/10.1139/f99-199.

TAGLIANI, C.R.A. Proposta para manejo integrado da exploração de areia no município costeiro de Rio Grande$R S$, dentro de um enfoque sistêmico [Master Thesis]. Sáo Leopoldo: UNISINOS, 1997; 157 p.
VAN DER OOST, R., BEYER, J. and VERMEULEN, N.P.E. Fish bioaccumulation and biomarkers in environmental risk assessment: a review. Environmental Toxicology and Pharmacology, 2003, 13(2), 57-149. http://dx.doi.org/10.1016/S13826689(02)00126-6. PMid:21782649

VIEIRA, J.L.F. and PASSARELLI, M.M. [Determination of total mercury in water samples, sediments and solids in suspension in aquatic systems by cold-vapor atomic absorption spectrophotometry]. Revista de Saude Publica, 1996, 30(3), 256-260. http:// dx.doi.org/10.1590/S0034-89101996000300008. PMid:9110471

WONG, L.C.Y. Future Challenges for the global rice market: a worm's eye view. In FAO Rice Conference. Rome, 2004.

ZAHIR, F., RIZWI, S.J., HAQ, S.K. and KHAN, R.H. Low dose mercury toxicity and human health. Environmental Toxicology and Pharmacology, 2005, 20(2), 351-360. http://dx.doi.org/10.1016/j. etap.2005.03.007. PMid:21783611

ZHANG, H., FENG, X., LARSSEN, T., QIU, G. and VOGT, R.D. In inland China, rice, rather than fish, is the major pathway for methylmercury exposure. Environmental Health Perspectives, 2010a, 118(9), 1183-1188. http://dx.doi.org/10.1289/ ehp.1001915. PMid:20378486

ZHANG, H., FENG, X., LARSSEN, T., SHANG, L. and LI, P. Bioaccumulation of methylmercury versus inorganic mercury in rice (Oryza sativa L.) grain. Environmental Science \& Technology, 2010b, 44(12), 4499-4504. http://dx.doi.org/10.1021/es903565t. PMid:20476782

ZHAO, K., LIU, X., XU, J. and SELIM, H.M. Heavy metal contaminations in a soil-rice system: identification of spatial dependence in relation to soil properties of paddy fields. Journal of Hazardous Materials, 2010, 181(1-3), 778-787. http://dx.doi.org/10.1016/j.jhazmat.2010.05.081. PMid:20561748

ZHOU, H.Y. and WONG, M.H. Mercury accumulation in freshwater fish with emphasis on dietary influences. Water Research, 2000, 34(17), 4234-4242. http:// dx.doi.org/10.1016/S0043-1354(00)00176-7.

ZHU, J., WANG, D., LIU, X. and ZHANG, Y. Mercury fluxes from air/surface interfaces in paddy field and dry land. Applied Geochemistry, 2011, 26(2), 249-255. http://dx.doi.org/10.1016/j. apgeochem.2010.11.025.

Received: 05 October 2014 Accepted: 24 February 2015 